\title{
Identifying the factors causing malnutrition and its impact on mortality among under-five Bangladeshi children
}

\author{
N.A.M. FAISAL AHMED ${ }^{1, A}, \mathrm{c}, \mathrm{E}, \mathrm{MAHMUDA}$ SULTANA ${ }^{2, A-E}, \mathrm{MOHAMMAD} \mathrm{ALI}^{2,}$ A-c, F, \\ ORCID ID: 0000-0001-8208-9579 \\ MD. MANIRUZZAMAN ${ }^{2, A-E}$ \\ ORCID ID: 0000-0001-6151-8071 \\ ${ }^{1}$ Institute of Education and Research, University of Rajshahi, Rajshahi, Bangladesh \\ ${ }^{2}$ Statistics Discipline, Khulna University, Khulna, Bangladesh \\ ${ }^{3}$ Department of Clinical Psychology, University of Rajshahi, Rajshahi, Bangladesh
} MD. MENHAZUL ABEDIN², A-D, BENOJIR AHAMMED2, A-D, F, MST. ANAMIKA YEASMIN ${ }^{3, A-D, F}$,

A - Study Design, B - Data Collection, C - Statistical Analysis, D - Data Interpretation, E - Manuscript Preparation, F - Literature Search, G - Funds Collection

Summary Background. Nutritional status is the best indicator of global well-being. Childhood malnutrition is a major public health problem among Bangladeshi children.

Objectives. The main objectives of this study are to: (i) determine the prevalence of malnutrition among under-five (U5) children; (ii) assess the association between malnutrition and selected factors; (iii) determine the high-risk factors for malnutrition and its impact on U5 mortality.

Material and methods. The data was taken from the Bangladesh Demographic and Health Survey (BDHS), 2014. Chi-square analysis was performed to explore the association between malnutrition and selected potential factors. Moreover, logistic regression (LR) was also performed to determine the factors associated with malnutrition and its impact on U5 mortality based on the $p$-value and odds ratio (OR) along with a $95 \%$ confidence interval (Cl).

Results. The prevalence of stunting, wasting and underweight were $37.1 \%, 14.7 \%$ and $33 \%$, respectively. Most of the selected factors were found to be highly significant $(p<0.05)$, which were performed via chi-square analysis. In the LR model, it was found that place of residence, region, mother's working status, mother's education, mother's age at first birth, wealth index and toilet facilities were the factors mostly responsible for child malnutrition. Our study also showed that wasting and underweight have a significant impact on U5 mortality.

Conclusions. It is recommended that educating mothers, delaying a mother's age for first birth, improving sanitation facilities, reducing poverty and creating health-related services are essential to improve a child's health and nutritional status. As a result, U5 mortality will be reduced in Bangladesh.

Key words: child, malnutrition, mortality, Bangladesh.

Ahmed NAMF, Sultana M, Ali M, Abedin MM, Ahammed B, Yeasmin MA, Maniruzzaman M. Identifying the factors causing malnutrition and its impact on mortality among under-five Bangladeshi children. Fam Med Prim Care Rev 2021; 23(3): 255-260, doi: https://doi. org/10.5114/fmpcr.2021.108185.

\section{Background}

Malnutrition is a major public health concern in any developing country and affects the physical and intellectual growth of young children. It is caused by deficiencies or lack of proper nutrients in the child's diet [1]. According to the report of the United Nations and International Food Policy Research Institute (IFPRI), there were about 2.3 million (i.e. 46\%) children under five (U5) years of age suffering from malnutrition. As a result, children are affected by various chronic diseases due to malnutrition [2,3]. About $50 \%$ of all child deaths occurred in those whose ages were less than five years due to malnutrition $[4,5]$. The overall prevalence of moderate to severe underweight in U5 children in Asian countries was $8 \%$ in China, $11 \%$ in Malaysia, $18 \%$ in Thailand, $28 \%$ in the Philippines, $47 \%$ in India and $48 \%$ in both Nepal and Bangladesh [6, 7].

There are three anthropometric indicators (Z-score for weight-for-height (wasting), Z-score for height-for-age (stunting), Z-score for weight-for-age (underweight)) commonly used to describe the nutritional status of the children [8]. Jesmin et al. [9] found that the effects of malnutrition on U5 children were permanent and cross into adulthood. Macro [10] showed that nutritional status was primarily measured by a child's growth in height and weight, which was directly influenced by food intake and the occurrence of infections. Babatunde and Qaim [11] reported that there was a significant relationship between the gender of a child and malnutrition. They also reported that male children were more likely to be malnourished than female children. This was probably due to increased attention paid to female children, unlike male children. Mahgoub et al. [12] showed that the gender of the child was also associated with stunting, wasting and underweight. They also showed that boys were more likely to be malnourished than girls. Islam and Biswas [13] found that a total of $15.7 \%$ of U5 children were underweight. Siddiqi et al. [14] studied malnutrition status among Bangladeshi children. They showed that the mother's age at first birth was associated with malnutrition. They indicated that the children whose mother's age at first birth was less than 20 years were 1.22 times more likely to be stunted, wasted and underweight compared to the children whose mother's age at first birth was greater than 20 years. It was found that the mother's education had a significant impact on the child's nutrition status [11, 15, 
16], as educated mothers are more conscious about the lifestyle of their children. Moreover, they very carefully look after their children's health status, hygiene, preventive care and disease treatment. Olwedo et al. [17] showed that a mother's responsibility to care for herself during pregnancy and her child throughout the most vulnerable stages of its life significantly affected U5 child malnutrition. Previous studies found that a mother's occupation was one of the determinants of U5 malnutrition in most developing countries [17-19], as working mothers left their children at home with other siblings who may neglect to feed them following the right frequency, and this sometimes worsens the problem of malnutrition. From literature reviews, it was noted that it is very necessary to take the proper steps to reduce child malnutrition, as well as U5 mortality.

\section{Objectives}

In our current study, the principal aims were to: (i) determine the prevalence of malnutrition among $U 5$ children; (ii) assess the association between malnutrition of U5 children and different socio-economic and demographic factors; (iii) determine the high-risk factors for malnutrition; and (iv) determine the impact of malnutrition on U5 mortality.

\section{Material and methods}

\section{Sources of data and study design}

Bangladesh Demographic and Health Survey (BDHS), 2014 data was used for conducting this study [20]. This was a nationally representative survey that covered the entire population in the country. The survey used a sampling frame from the list of enumeration areas (EA) of 2011 populations and the housing census of the population in Bangladesh, which was provided by the Bangladesh Bureau of Statistics (BBS). The primary sampling unit (PSU) for the survey was an EA created to have an average of about 120 households. BDHS, 2014 was used as a two-stage stratified sample of households. In the first stage, 600 EAs were selected with a probability proportional to the EA size, and in the second stage, 30 households were selected based on systematic sampling. Using this design, 18,0000 residential households were selected for this survey, and we expected to complete interviews with about 18,000 ever-married women between the age of 15-49 years. A total of 17,863 ever-married women between the age of 15-49 years were interviewed. The details of the study design and sample collection procedures were described in literature [21]. In our current study, the kids recode (KR) dataset was used, which contained the information of U5 children. The dataset consisted of 7,886 observations and contained some missing values. After excluding the missing values, there were about 6,341 observations selected for final analysis.

\section{Response variable}

The major purpose of the current study was to determine the factors associated with U5 child malnutrition, as well as its impact on U5 mortality. The response variable was defined as follows:

$$
\begin{aligned}
& Y_{\text {Stunting }}=\left\{\begin{array}{l}
1, \text { If } \mathrm{HAZ}<-2 \\
0, \text { Otherwise }
\end{array}\right. \\
& Y_{\text {Wasting }}=\left\{\begin{array}{l}
1, \text { If } \mathrm{WHZ}<-2 \\
0, \text { Otherwise }
\end{array}\right. \\
& Y_{\text {Underweight }}=\left\{\begin{array}{l}
1, \text { If WAZ<-2 } \\
0, \text { Otherwise }
\end{array}\right. \\
& Y_{\text {U5 mortality }}=\left\{\begin{array}{l}
1, \text { If child is dead } \\
0, \text { Otherwise }
\end{array}\right.
\end{aligned}
$$

The Z-score was calculated based on age, height and weight by using the WHO Anthroplus Software version 3.2.2, 2011.

\section{Explanatory variables}

In this study, we selected eleven explanatory variables. The definition, category and description of the selected explanatory variables are described in Table 1.

\begin{tabular}{|l|l|l|}
\hline \multicolumn{3}{|l|}{ Table 1. Definition, category and description of the selected } \\
explanatory variables
\end{tabular}

\section{Statistical analysis}

Univariate analysis was used to explore the background characteristics of the selected explanatory variables. Chi-square analysis was adopted to assess the association between malnutrition and different selected factors. Logistic regression (LR) was used to identify the determinants of malnutrition, as well as show the impact of malnutrition on U5 mortality based on the $p$-value and odds ratio (OR). In this study, we considered high-risk factors as those whose $p$-value is less than 0.05 and the value of $O R$ is greater than 1 . The details of the interpretation of OR were described in [22]. All statistical analysis was performed using Statistical Package for Social Science (SPSS) version 20.

\section{Ethical approval}

This study was based on an analysis of existing public domain survey datasets that are freely available online with all identifier information removed. The survey was approved by 
the Ethics Committee of the ICF International, USA, and the National Research Ethics Committee of Bangladesh Medical Research Council (BMRC), Bangladesh. The authors were granted permission to use the data for independent research purposes.

\section{Results}

\section{Association between malnutrition status and selec- ted explanatory variables}

The overall prevalence of stunting, wasting and underweight was $37.1 \%, 14.7 \%$ and $33 \%$, respectively. Table 2 presents the association between a U5 child's nutrition status and selected explanatory variables using the chi-square analysis. It was observed that the gender of a child is not associated with stunting and underweight, but it is associated with wasting ( $p=$ $0.016)$. It was noted that wasting in males $(15.7 \%)$ was higher than in females (13.7\%). Table 2 indicates that there is a highly significant association between a child's age (months) and a U5 child's malnutrition status (stunting, wasting and underweight) $(p<0.001)$. We observed that $42 \%$ of children $13-36$ months or age were stunted, $18 \%$ of those less than 12 months of age were wasted, and $37.7 \%$ of those $37-59$ months of age were underweight. It was observed that the place of residence is associated with stunting, wasting and underweight. It was observed that children who live in rural areas have higher percentages of being stunted, wasted and underweight compared to those from urban areas. The mother's education is also associated with stunting, wasting and underweight. We observes that the percentages of stunting, wasting and underweight are higher for mothers who have no education. Working mothers have the highest percentage of stunted (40.3\%), wasted (16.1\%) and underweight (37.4\%) children compared to mothers who do not engage in any work. The mother's age at first birth is associated with malnutrition status. Mothers who had their first birth at

\begin{tabular}{|c|c|c|c|c|c|c|c|}
\hline \multirow[t]{2}{*}{ Explanatory variable } & \multirow{2}{*}{$\begin{array}{l}\text { Overall, } \\
n(\%)\end{array}$} & \multicolumn{2}{|l|}{ HAZ } & \multicolumn{2}{|l|}{ WHZ } & \multicolumn{2}{|l|}{ WAZ } \\
\hline & & $\begin{array}{l}\text { Stunting, } \\
n(\%)\end{array}$ & $p$ & $\begin{array}{l}\text { Wasting, } \\
n(\%)\end{array}$ & $p$ & $\begin{array}{l}\text { Underweight } \\
n(\%)\end{array}$ & $p^{1}$ \\
\hline $\begin{array}{l}\text { Gender of child } \\
\text { male } \\
\text { female }\end{array}$ & $\begin{array}{l}3261(51.4) \\
3080(48.6)\end{array}$ & $\begin{array}{l}1235(37.9) \\
1118(36.3)\end{array}$ & 0.102 & $\begin{array}{l}511(15.7) \\
423(13.7)\end{array}$ & 0.016 & $\begin{array}{l}1062(32.6) \\
1030(33.0)\end{array}$ & 0.238 \\
\hline $\begin{array}{l}\text { Age of child (months) } \\
\leq 12 \\
13-36 \\
37-59\end{array}$ & \begin{tabular}{|l|}
$1286(20.3)$ \\
$2604(41.1)$ \\
$2451(38.7)$ \\
\end{tabular} & $\begin{array}{l}239(18.6) \\
1094(42.0) \\
1020(41.6) \\
\end{array}$ & $<0.001$ & $\begin{array}{l}231(18.0) \\
359(13.8) \\
344(14.0)\end{array}$ & 0.001 & $\begin{array}{l}269(20.9) \\
899(34.5) \\
924(37.7) \\
\end{array}$ & $<0.001$ \\
\hline $\begin{array}{l}\text { Place of residence } \\
\text { urban } \\
\text { rural }\end{array}$ & \begin{tabular}{|l|}
$2027(32.0)$ \\
$4314(68.0)$ \\
\end{tabular} & \begin{tabular}{|l}
$662(32.7)$ \\
$1691(39.2)$ \\
\end{tabular} & $<0.001$ & $\begin{array}{l}247(12.2) \\
687(15.9) \\
\end{array}$ & $<0.001$ & \begin{tabular}{|l|}
$562(27.7)$ \\
$1530(35.5)$ \\
\end{tabular} & $<0.001$ \\
\hline $\begin{array}{l}\text { Mother's education } \\
\text { no education } \\
\text { primary } \\
\text { secondary } \\
\text { higher }\end{array}$ & $\begin{array}{l}1031(16.3) \\
1777(28.0) \\
2891(45.6) \\
642(10.1)\end{array}$ & $\begin{array}{l}516(50.0) \\
801(45.1) \\
906(31.3) \\
130(20.2)\end{array}$ & $<0.001$ & $\begin{array}{l}159(15.4) \\
300(16.9) \\
399(13.8) \\
76(11.8)\end{array}$ & 0.004 & $\begin{array}{l}450(43.6) \\
705(39.7) \\
816(28.2) \\
121(18.8)\end{array}$ & $<0.001$ \\
\hline $\begin{array}{l}\text { Mother's working status } \\
\text { no } \\
\text { yes }\end{array}$ & \begin{tabular}{|l}
4685 (73.9) \\
1656 (26.1) \\
\end{tabular} & $\begin{array}{l}1685(36.0) \\
668(40.3) \\
\end{array}$ & $<0.001$ & $\begin{array}{l}667(14.2) \\
267(16.1)\end{array}$ & 0.035 & $\begin{array}{l}1473(31.4) \\
619(37.4) \\
\end{array}$ & $<0.001$ \\
\hline $\begin{array}{l}\text { Mother's age at first birth (years) } \\
<17 \\
17\end{array}$ & $\begin{array}{l}2908(45.9) \\
3433(54.1) \\
\end{array}$ & $\begin{array}{l}1210(41.6) \\
1143(33.3) \\
\end{array}$ & $<0.001$ & $\begin{array}{l}463(15.9) \\
471(13.7) \\
\end{array}$ & 0.008 & \begin{tabular}{|l}
$1078(37.1)$ \\
$1014(29.5)$ \\
\end{tabular} & $<0.001$ \\
\hline $\begin{array}{l}\text { Birth order } \\
1 \\
>1\end{array}$ & $\begin{array}{l}2318(36.6) \\
4023(63.4)\end{array}$ & $\begin{array}{l}752(32.4) \\
1601(39.8)\end{array}$ & $<0.001$ & $\begin{array}{l}341(14.7) \\
593(14.7)\end{array}$ & 0.503 & \begin{tabular}{|l}
$707(30.5)$ \\
$1385(34.4)$
\end{tabular} & 0.001 \\
\hline $\begin{array}{l}\text { Region } \\
\text { Barisal } \\
\text { Chittagong } \\
\text { Dhaka } \\
\text { Khulna } \\
\text { Rajshahi } \\
\text { Rangpur } \\
\text { Sylhet } \\
\end{array}$ & \begin{tabular}{|l|}
$735(11.6)$ \\
$1199(18.9)$ \\
$1109(17.5)$ \\
$707(11.1)$ \\
$781(12.3)$ \\
$782(12.3)$ \\
$1028(16.2)$ \\
\end{tabular} & $\begin{array}{l}281(38.2) \\
453(37.8) \\
373(33.6) \\
209(29.6) \\
239(30.6) \\
284(36.3) \\
514(50.0) \\
\end{array}$ & $<0.001$ & $\begin{array}{l}127(17.3) \\
186(15.5) \\
135(12.2) \\
98(13.9) \\
138(17.7) \\
126(16.1) \\
124(12.1) \\
\end{array}$ & 0.001 & $\begin{array}{l}249(33.9) \\
414(34.5) \\
305(27.5) \\
194(27.4) \\
253(32.4) \\
265(33.9) \\
412(40.1) \\
\end{array}$ & $<0.001$ \\
\hline $\begin{array}{l}\text { Wealth index } \\
\text { poor } \\
\text { average } \\
\text { rich }\end{array}$ & \begin{tabular}{|l|}
$2592(40.9)$ \\
$1232(19.4)$ \\
$2517(39.7)$ \\
\end{tabular} & $\begin{array}{l}1230(47.5) \\
473(38.4) \\
650(25.8) \\
\end{array}$ & $<0.001$ & $\begin{array}{l}464(17.9) \\
178(14.4) \\
292(11.6) \\
\end{array}$ & $<0.001$ & \begin{tabular}{|l|}
$1108(42.7)$ \\
$409(33.2)$ \\
$575(22.8)$ \\
\end{tabular} & $<0.001$ \\
\hline $\begin{array}{l}\text { Source of drinking water } \\
\text { improved } \\
\text { unimproved }\end{array}$ & \begin{tabular}{|l|}
$6172(97.3)$ \\
$169(2.7)$ \\
\end{tabular} & $\begin{array}{l}2281(37.0) \\
72(42.6) \\
\end{array}$ & 0.079 & \begin{tabular}{|l}
$898(14.5)$ \\
$36(21.3)$ \\
\end{tabular} & 0.012 & $\begin{array}{l}2023(32.8) \\
69(40.8) \\
\end{array}$ & 0.018 \\
\hline $\begin{array}{l}\text { Toilet facilities } \\
\text { improved } \\
\text { unimproved }\end{array}$ & \begin{tabular}{|l}
$1962(30.9)$ \\
$4379(69.1)$
\end{tabular} & $\begin{array}{l}512(26.1) \\
1841(42.0)\end{array}$ & $<0.001$ & $\begin{array}{l}241(12.3) \\
693(15.8)\end{array}$ & $<0.001$ & \begin{tabular}{|l}
$457(23.3)$ \\
$1635(37.3)$
\end{tabular} & $<0.001$ \\
\hline
\end{tabular}

${ }^{1}$ The $p$-value was obtained using the $\chi^{2}$ test. 
an age less than 17 years have higher percentages of stunting, wasting and underweight children compared to a mother who had their child at an age greater than 17 years. Birth order is associated with stunting and underweight but not wasting. The percentages of stunting and underweight are higher for those above the first birth order. Table 2 shows that the region is also associated with both stunted and underweight children.

Surprisingly, the Sylhet region had the highest percentage for both stunted and underweight children rather than the wasted children. The wealth index was also associated with child malnutrition. In the case of poor families, the highest percentages of stunted, wasted and underweight were $47.5 \%, 17.9 \%$ and $42.7 \%$, respectively. The percentage of stunted, wasted and underweight children was the lowest in rich families. The source of drinking water had a significant impact on wasting and underweight children. We observed that a child's family who was drinking unimproved water had the highest prevalence of wasting $(21.3 \%)$ and underweight $(40.8 \%)$. It was observed that toilet facilities were also associated with stunting, wasting and underweight. It was also observed that a child's family who has unimproved toilet facilities had the highest percentages of stunting, wasting and underweight.

\section{Identification of factors of malnutrition using logi- stic regression}

The LR model was used to identify the determinants of U5 child malnutrition, and the results are presented in Table 3. Table 3 indicates that the gender of the child has a significant impact on wasting. It was observed that female children are 0.855 (OR $=0.855,95 \% \mathrm{Cl}=0.742-0.984$ ) times less at risk of wasting compared to males. The age of the child has a significant impact on both stunting, wasting and underweight. It was noted that the children aged 13-36 months and 37-59 months had 0.296 (OR $=0.296,95 \% \mathrm{Cl}=0.251-0.350)$ and 0.318 (OR $=0.318,95 \%$ $\mathrm{Cl}=0.269-0.377)$ times lower risk of stunting compared to the children aged less than 12 months. Similarly, children aged 13-36 months and 37-59 months are 0.495 (OR $=0.495,95 \%$ $\mathrm{Cl}=0.422-0.582)$ and $0.450(\mathrm{OR}=0.450,95 \% \mathrm{Cl}=0.383-0.529)$ times less likely to be underweight than their counterparts who are less than 12 months of age. It was also observed that the children whose ages were 13-36 months and 37-59 months were $1.382(\mathrm{OR}=1.382,95 \% \mathrm{Cl}=1.152-1.659)$ and $1.374(\mathrm{OR}=1.374$, $95 \% \mathrm{Cl}=1.142-1.654)$ times more likely to be wasted compared to the children whose ages were less than 12 months. The odds

\begin{tabular}{|c|c|c|c|}
\hline Variables & $\begin{array}{l}\text { Model-1 } \\
\text { OR }(95 \% \mathrm{Cl})\end{array}$ & $\begin{array}{l}\text { Model-2 } \\
\text { OR }(95 \% \mathrm{CI})\end{array}$ & $\begin{array}{l}\text { Model-3 } \\
\text { OR }(95 \% \mathrm{CI})\end{array}$ \\
\hline $\begin{array}{l}\text { Gender of child } \\
\text { male (Ref) } \\
\text { female }\end{array}$ & & $\begin{array}{l}1.000 \\
0.855(0.742,0.984)^{*}\end{array}$ & \\
\hline $\begin{array}{l}\text { Age of child (months) } \\
\leq 12 \text { (Ref) } \\
13-36 \\
37-59\end{array}$ & $\begin{array}{l}1.000 \\
0.296(0.251,0.350)^{*} \\
0.318(0.269,0.377)^{*}\end{array}$ & $\begin{array}{l}1.000 \\
1.382(1.152,1.659)^{*} \\
1.374(1.142,1.654)^{*}\end{array}$ & $\begin{array}{l}1.000 \\
0.495(0.422,0.582)^{*} \\
0.450(0.383,0.529)^{*}\end{array}$ \\
\hline $\begin{array}{l}\text { Place of residence } \\
\text { urban (Ref) } \\
\text { rural }\end{array}$ & $\begin{array}{l}1.000 \\
1.172(1.027,1.337)^{*}\end{array}$ & $\begin{array}{l}1.000 \\
1.266(1.027,1.332)^{*}\end{array}$ & \begin{tabular}{|l}
1.000 \\
$1.023(0.896,1.169)$
\end{tabular} \\
\hline $\begin{array}{l}\text { Mother's education } \\
\text { no education (Ref) } \\
\text { primary } \\
\text { secondary } \\
\text { higher }\end{array}$ & \begin{tabular}{|l|}
1.000 \\
$0.957(1.931,1.289)$ \\
$0.763(0.255,1.742)^{*}$ \\
$0.614(0.482,2.492)^{*}$
\end{tabular} & $\begin{array}{l}1.000 \\
0.890(0.719,1.102) \\
0.296(0.147,1.302)^{*} \\
0.102(0.095,0.529)^{*}\end{array}$ & $\begin{array}{l}1.000 \\
0.890(0.927,1.281) \\
0.447(0.228,0.705)^{*} \\
0.234(0.212,0.391)^{*}\end{array}$ \\
\hline $\begin{array}{l}\text { Mother's working status } \\
\text { no (Ref) } \\
\text { yes }\end{array}$ & \begin{tabular}{|l}
1.000 \\
$1.212(0.805,1.233)^{*}$
\end{tabular} & $\begin{array}{l}1.000 \\
1.291(0.759,1.246)\end{array}$ & \begin{tabular}{|l}
1.000 \\
$1.239(0.740,1.450)^{*}$
\end{tabular} \\
\hline $\begin{array}{l}\text { Mother's age at first birth (years) } \\
<17 \text { (Ref) } \\
\geq 17\end{array}$ & $\begin{array}{l}1.000 \\
1.182(1.056,1.323)^{*}\end{array}$ & $\begin{array}{l}1.000 \\
0.938(0.810,1.086)\end{array}$ & $\begin{array}{l}1.000 \\
0.861(0.768,0.964)^{*}\end{array}$ \\
\hline $\begin{array}{l}\text { Birth order } \\
1 \text { (Ref) } \\
>1\end{array}$ & $\begin{array}{l}1.000 \\
0.939(0.835,1.057)\end{array}$ & & \begin{tabular}{|l}
1.000 \\
$1.076(0.955,1.212)$
\end{tabular} \\
\hline $\begin{array}{l}\text { Region } \\
\text { Barisal (Ref) } \\
\text { Chittagong } \\
\text { Dhaka } \\
\text { Khulna } \\
\text { Rajshahi } \\
\text { Rangpur } \\
\text { Sylhet } \\
\end{array}$ & \begin{tabular}{|l}
1.000 \\
$0.863(0.706,1.056)$ \\
$1.024(0.831,1.261)$ \\
$1.324(1.051,1.668)^{*}$ \\
$1.392(1.111,1.743)^{*}$ \\
$1.177(0.944,1.466)$ \\
$0.607(0.493,0.746)^{*}$ \\
\end{tabular} & $\begin{array}{l}1.000 \\
0.652(0.495,0.859)^{*} \\
0.675(0.525,0.867)^{*} \\
0.879(0.672,1.149) \\
0.810(0.605,1.084) \\
0.619(0.471,0.813)^{*} \\
0.712(0.540,0.939)^{*}\end{array}$ & $\begin{array}{l}1.000 \\
1.292(1.049,1.591)^{*} \\
1.068(0.890,1.281) \\
1.500(1.237,1.817)^{*} \\
1.573(1.264,1.957)^{*} \\
1.359(1.104,1.673)^{*} \\
1.383(1.125,1.701)^{*} \\
\end{array}$ \\
\hline $\begin{array}{l}\text { Wealth index } \\
\text { poor (Ref) } \\
\text { average } \\
\text { rich }\end{array}$ & $\begin{array}{l}1.000 \\
0.281(0.102,1.488)^{*} \\
0.064(0.739,2.450)^{*}\end{array}$ & $\begin{array}{l}1.000 \\
0.235(0.213,1.505)^{*} \\
0.448(0.255,1.817)^{*}\end{array}$ & $\begin{array}{l}1.000 \\
0.337(0.150,0.556)^{*} \\
0.300(0.298,0.960)^{*}\end{array}$ \\
\hline $\begin{array}{l}\text { Source of drinking water } \\
\text { improved (Ref) } \\
\text { unimproved }\end{array}$ & & $\begin{array}{l}1.000 \\
0.646(0.439,0.950)\end{array}$ & $\begin{array}{l}1.000 \\
0.904(0.652,0.955)\end{array}$ \\
\hline $\begin{array}{l}\text { Toilet facilities } \\
\text { improved (Ref) } \\
\text { unimproved }\end{array}$ & $\begin{array}{l}1.000 \\
1.812(1.696,1.948)^{*}\end{array}$ & $\begin{array}{l}1.000 \\
1.063(0.866,1.304)\end{array}$ & \begin{tabular}{|l}
1.000 \\
$1.863(1.737,2.010) *$
\end{tabular} \\
\hline
\end{tabular}

Ref = reference category; $\mathrm{Cl}=$ confidence interval. Stunting, wasting and underweight are used as the response variable in Model-1, Model-2 and Model-3, respectively. ${ }^{*}$ Indicates significant factors at a $5 \%$ level of significance. 
ratio for stunted and wasted children who live in the rural areas is $1.172(\mathrm{OR}=1.172,95 \% \mathrm{Cl}=1.027-1.337)$ and $1.266(\mathrm{OR}=$ $1.266,95 \% \mathrm{Cl}=1.027-1.332$ ) times higher than a child who lives in urban areas. The mother's education has a significant impact on stunting, wasting and underweight. With mothers who have completed secondary and higher education, the risk of a child being stunted would then be expected to decrease by 0.763 and 0.614 times than a mother with no education. Similarly, for wasting and underweight, the results are similar. The mother's working status had a significant impact on stunting and underweight. Mothers who are currently working have 1.212 times $(\mathrm{OR}=1.212,95 \% \mathrm{Cl}=0.805-1.233)$ and $1.239(\mathrm{OR}=1.239,95 \%$ $\mathrm{Cl}=0.740-1.450)$ times more chance of their children being stunted and underweight than mothers who are not engaged in working. Mothers who have their first birth at an age greater than 17 years are $1.182(\mathrm{OR}=1.182,95 \% \mathrm{Cl}=1.056-1.323)$ times more at risk of the child being stunting and 0.861 (OR = $0.861,95 \% \mathrm{Cl}=0.768-0.964)$ times less at risk of the child being underweight compared to mothers who have their first birth at an age less than 17 years. Region also had a significant impact on child malnutrition.

Compared to the Barisal region, it was observed that children who come from Khulna and Rajshahi are 1.324 (OR = $1.324,95 \% \mathrm{Cl}=1.051-1.668)$ and $1.392(\mathrm{OR}=1.392,95 \% \mathrm{Cl}=$ 1.111-1.743) times more at risk of being stunted, while those from the Sylhet region are 0.607 less at risk. Similarly, children from Chittagong, Dhaka, Rangpur and Sylhet are 0.652, 0.675, 0.619 and 0.712 times less at risk of being wasted compared to those from the Barisal region. Children who come from the Chittagong, Khulna, Rajshahi, Rangpur and Sylhet regions have a higher risk of being underweight compared to Barisal. Wealth index has a significant impact on child nutrition status. Children with a wealth index of average or rich are 0.281 and 0.064 times less likely to be stunted compared to the poor. It was also found that children with a wealth index of average or rich are 0.235 and 0.448 times less likely to be wasted than the poor. For the underweight category, children with a wealth index of average or rich are 0.337 and 0.300 times less likely to be underweight than the poor. Toilet facilities is a significant indicator of stunting and underweight. Table 3 shows that the respondents who used an unimproved toilet have children who are 1.812 times more likely of being stunted and 1.863 times more likely of being underweight than those with an improved toilet.

\section{Impact of malnutrition on under-five mortality}

The main objective of this section is to show the impact of malnutrition (stunting, wasting and underweight) on U5 mortality, which is depicted in Table 4 . The overall U5 mortality is

\begin{tabular}{|c|c|c|c|c|}
\hline \multirow[t]{2}{*}{ Factors } & \multicolumn{2}{|c|}{ U5 Morality } & \multicolumn{2}{|l|}{ Model-4 } \\
\hline & Yes, $n(\%)$ & No, $n(\%)$ & OR $(95 \% \mathrm{Cl})$ & $p$ \\
\hline \multicolumn{5}{|l|}{ HAZ } \\
\hline$<-2$ & $74(31.4)$ & 2279 (37.3) & $\begin{array}{l}1.304 \\
(0.986,1.725)\end{array}$ & 0.063 \\
\hline$>=-2(\operatorname{Ref})$ & $162(68.6)$ & $3826(62.7)$ & 1.000 & \\
\hline \multicolumn{5}{|l|}{ WHZ } \\
\hline$<-2$ & $24(10.2)$ & 910 (14.9) & \begin{tabular}{|l|}
1.547 \\
$(1.009,2.374)$ \\
\end{tabular} & 0.046 \\
\hline$>=-2(\operatorname{Ref})$ & $212(89.8)$ & $5195(85.1)$ & 1.000 & \\
\hline \multicolumn{5}{|l|}{ WAZ } \\
\hline$<-2$ & $60(25.4)$ & $2032(33.3)$ & \begin{tabular}{l|}
1.463 \\
$(1.087,1.971)$
\end{tabular} & 0.012 \\
\hline$>=-2(\operatorname{Ref})$ & $176(74.6)$ & 4073 (66.7) & 1.000 & \\
\hline
\end{tabular}

$\mathrm{HAZ}<-2$, stunting; $\mathrm{WHZ}<-2$, wasting; $\mathrm{WAZ}<-2$, underweight. In Model 4, U5 mortality is considered a response variable, and stunting, wasting and underweight are considered independent variables.
236 (3.7\%), and among this, 74 (31.4\%) for stunting, 24 (10.2\%) for wasting and $60(25.4 \%)$ for under-weight. It was observed that wasting and underweight are statistically associated with U5 mortality. It was also observed that children who are in the wasting stages and underweight are $1.547(\mathrm{OR}=1547,95 \% \mathrm{Cl}$ $=1.009-2.374)$ and $1.463(\mathrm{OR}=1.463,95 \% \mathrm{Cl}=1.087-1.971)$ times more at risk of U5 deaths compared to a normal child.

\section{Discussion}

We adopted both the Chi-square and LR model in this study. In the Chi-square analysis, most of the selected factors were significantly associated with the nutritional status of children. In $L R$, the present study noticed that place of residence was the main determinant of all three types of malnutrition. Children who lived in rural areas were more likely to show stunting, wasting and underweight compared to urban areas. Previous studies also stated the same result [11,21]. A higher prevalence of malnutrition was found in family members with no education [11, 15-17]. In agreement, this study showed a lower risk of malnourished children whose mothers had higher education as compared to mothers with no education. As educated mothers have enough knowledge about their children's health and nutrition, the nutritional status of children can be developed through the improvement of child care, hygiene, sanitation, etc. It was also found that mothers who are currently working have a higher chance of their children being malnourished compared to mothers who are not engaged in work. Several studies also showed the same result $[24,25]$. There is a 1.182 times higher chance of U5 children being stunted with mothers who have their first birth at an age above 17 compared to mothers who are below 17 years of age. There is a 0.938 and 0.861 times lower chance for a U5 child being wasted and underweight with mothers who have their first birth at an age above 17 relative to mothers who have their first birth at an age below 17 years.

Endris et al. [22] and Sommerfelt and Stewart [25] showed that a child's birth order number has a significant effect on a child's malnutrition. In our current study, we found that children who were born in another order than the first order had a lower chance of being stunted than those who were first born, and those who were born in another other than first order had a higher chance of being underweight than those who were first born. Endris et al. [22] indicated that wealth index was a strong indicator of child nutrition status. Our current results also provide the same result. Another factor of all three types of malnutrition is toilet facilities. In respondents who used an unimproved toilet, their children were more likely to be stunted, wasted and underweight compared to those who used an improved toilet. This was consistent with other studies $[2,26]$. In our current study, we also showed that wasting and underweight also had a significant impact on U5 mortality.

\section{Strength, limitation and extension of the current study}

This study utilizes eleven covariates using the latest BDHS, 2014 dataset. This study shows the three anthropometric indicators (stunting, wasting and underweight) in child malnutrition separately. Firstly, we identified the factors causing malnutrition and their impact on U5 mortality. Some limitations arise from this study, as we have used cross-sectional data. In this data, there were some missing values, and we exclude the missing values from the analysis. As a result, a lot of information was omitted from the analysis. The analysis would be more accurate if we estimated the missing values. The DHS data for Bangladesh was based on participants' self-reports, with no scope of validation by the interviewers, and could suffer from report or recall bias. Lastly, there were several problems, such as limited time, lack of manpower and shortage of funds. In the future, we will 
estimate the missing values using different multivariate techniques and predict child malnutrition status using a machine learning-based paradigm.

\section{Conclusions}

In this study, we have tried to identify the determinant of U5 child malnutrition and its impact on U5 mortality. In the Chi-square analysis, birth order, mother's education, mother's working status, region of residence, type of residence, wealth index and toilet facilities were associated with malnutrition sta- tus. In LR, mother's working status, mother's education, wealth indexes and place of residence were the most significant factors of malnutrition. The government should take proper steps based on our findings to reduce child malnutrition and U5 mortality in Bangladesh.

Acknowledgements. The authors thankfully acknowledge the contribution of the Statistics Discipline, Khulna University, Khulna-9208, Bangladesh. We express our sweet acknowledgements to our sweet surroundings of well-wishers and friends for their kind co-operation and inspiration throughout the work.

Source of funding: This work was funded from the authors' own resources.

Conflicts of interest: The authors declare no conflicts of interest.

\section{References}

1. Park K. Park's textbook of preventive and social medicine nutrition and health. 21st ed. India: Bhanol Publisher; 2011.

2. Rahman A, Chowdhury S. Determinants of chronic malnutrition among preschool children in Bangladesh. J Biosc Sci 2011; 39(2): 161-173.

3. Rayhan MI, Khan MSH. Factor's causing malnutrition among under-five children in Bangladesh. Pakistan J Nutr 2006; 5(6): 558-562.

4. Pelletier DL, Frongillo EA Jr, Schroeder DG, et al. The effects of malnutrition on child mortality in developing countries. Bull World Health Organ 1995; 73: 443-448

5. Srilakshmi B. Nutrition science. New Delhi, Delhi: New Age International; 2006.

6. Khor GL. Food-based approaches to combat the double burden among the poor: challenges in the Asian context. Asia Pac J Clin Nutr 2008; 17(Suppl. 1): 111-115.

7. Rachmi CN, Agho KE, Li M, et al. Stunting, underweight and overweight in children aged 2.0-4.9 years in Indonesia: prevalence trends and associated risk factors. PloS ONE 2006; 11(5): e0154756.

8. Acharya D, Gautam S, Kaphle HP, et al. Factors associated with nutritional status of under-five children in Rupandehi District of Nepal. JHAS 2013; 3: 56-59.

9. Jesmin A, Yamamoto SS, Malik AA, et al. Prevalence and determinants of chronic malnutrition among preschool children: a crosssectional study in Dhaka City, Bangladesh. J Health Popul Nutr 2011; 29(5): 494.

10. Ghana Statistical Service (GSS), Ghana Health Service (GHS), ICF Macro. Ghana Demographic and Health Survey 2008. Accra, Ghana: GSS, GHS, ICF Macro; 2009.

11. Babatunde RO, Qaim M. Impact of off-farm income on food security and nutrition in Nigeria. Food Policy 2010; 35(4): 303-311.

12. Mahgoub SEO, Nnyepi M, Bandeke T. Factors affecting prevalence of malnutrition among children under three years of age in Botswana. AJFAND 2006; 6(1). Available from URL: http://www.ajfand.net/Volume6/No1/Mahgoub1420.pdf.

13. Islam A, Biswas T. Chronic stunting among under-5 children in Bangladesh: a situation analysis. Advances in Pediatric Research 2015; 2: 18.

14. Siddiqi MNA, Haque MN, Goni MA. Malnutrition of under-five children: evidence from Bangladesh. AJMS 2011; 2(2): $113-119$.

15. Webb P, Block S. Nutrition information and formal schooling as inputs to child nutrition. Economic Development and Cultural Change 2004; 52(4): 801-820.

16. Shrimpton R, Victora CG, de Onis $\mathrm{M}$, et al. Worldwide timing of growth faltering: implications for nutritional interventions. Pediatrics 2001; 107(5): e75, doi: 10.1542/peds.107.5.e75.

17. Olwedo MA, Mworozi E, Bachou $\mathrm{H}$, et al. Factors associated with malnutrition among children in internally displaced person's camps, northern Uganda. Afr Health Sci 2008; 8(4): 244-252.

18. Hien NN, Kam, S. Nutritional status and the characteristics related to malnutrition in children under-five years of age in Nghean, Vietnam. J Prev Med Public Health 2008; 41(4): 232-240.

19. Rukundo T. Protein Energy Malnutrition among the under-five; a situation analysis for Jinja district. Kampala, Uganda: Fountain Publishers Limited; 1988.

20. National Institute of Population Research and Training (NIPORT), Mitra and Associates, ICF International. Bangladesh Demographic and Health Survey 2014. Dhaka, Bangladesh: NIPORT, Mitra and Associates, Rockville, Maryland, USA: ICF International; 2016. Available from URL: https://dhsprogram.com/pubs/pdf/FR311/FR311.pdf.

21. Maniruzzaman M, Suri HS, Kumar N, et al. Risk factors of neonatal mortality and child mortality in Bangladesh. J Glob Health 2018; 8(1): 010417, doi: 10.7189/jogh.08.010421.

22. Endris N, Asefa H, Dube L. Prevalence of malnutrition and associated factors among children in rural Ethiopia. Biomed Res Int 2017; 2017: 6587853, doi: 10.1155/2017/6587853.

23. Alom J, Islam MA, Quddus M. Socioeconomic factors influencing nutritional status of under-five children of Agrarian families in Bangladesh: a multilevel analysis. Bangladesh. Bangladesh J Agric Econs 2009; 32: 63-74.

24. Chowdhury MRK, Rahman MS, Khan MMH, et al. Risk factors for child malnutrition in Bangladesh: a multilevel analysis of a nationwide population-based survey. J Pediatr 2016; 172: 194-201.

25. Sommerfelt AE, Stewart MK. Children's nutritional status. DHS Comparative Studies No. 12. Calverton, Maryland: Macro International Inc.; 1994.

26. Das S, Hossain MZ, Islam MA. Predictors of child chronic malnutrition in Bangladesh. Cell 2008; 880: 1818824282.

Tables: 4

Figures: 0

References: 26

Received: 22.09 .2020

Reviewed: 29.09.2020

Accepted: 16.11 .2020
Address for correspondence:

Md. Maniruzzaman, MSc

Statistics Discipline, Khulna University

Khulna

Bangladesh

Tel.: +880 1737095565

E-mail: monir.stat91@gmail.com 